2015

\title{
A Parade of Reforms: The European Commission's Latest Proposal for ISDS
}

Gus Van Harten

Osgoode Hall Law School of York University, gvanharten@osgoode.yorku.ca

Follow this and additional works at: http:// digitalcommons.osgoode.yorku.ca/olsrps

Part of the Dispute Resolution and Arbitration Commons, and the International Law Commons

\section{Recommended Citation}

Van Harten, Gus, "A Parade of Reforms: The European Commission's Latest Proposal for ISDS" (2015). Osgoode Legal Studies Research Paper Series. 102.

http://digitalcommons.osgoode.yorku.ca/olsrps/102 
Osgoode Legal Studies Research Paper No. 21

Vol. 11/ Issue. 05/ (2015)

\title{
A parade of reforms: The European Commission's latest proposal for ISDS
}

\author{
Gus Van Harten
}

\begin{abstract}
:

\section{Keywords:}

\author{
Author(s): \\ Gus Van Harten \\ Osgoode Hall Law School \\ York University, Toronto \\ E: gvanharten@osgoode.yorku.ca
}

The European Commission's most recent proposal for ISDS reflects a move away from essentially fake reforms to something potentially more meaningful. However, it is insufficient to satisfy the criteria of independence, fairness, openness, subsidiarity, and balance and does not appear reliable until backed by clear language and a negotiating red line for the proposed Canada-Europe CETA and any other agreement providing for ISDS.

ISDS, TTIP, CETA, investment court, arbitration, European Commission 


\title{
A parade of reforms: the European Commission's latest proposal for ISDS
}

\author{
Gus Van Harten \\ Osgoode Hall Law School \\ gvanharten@osgoode.yorku.ca \\ May 5, 2015, revised May 6 [to incorporate a copy-edit]
}

\begin{abstract}
The debate over ISDS in Europe has generated several examples of how the term "reform" can be used to promote investor-state dispute resolution (ISDS), without altering the essential transfer of power and effective subsidy inherent in ISDS.
\end{abstract}

The most recent proposal emenging from the European Commission is an example. As I explain in this paper, the most recent proposal (a) reflects a move away from essentially fake reforms to something potentially more meaningful but (b) is insufficient to satisfy the minimum criteria of independence, fairness, openness, subsidiarity, and balance, and (c) is not reliable until it is backed by clear language and a negotiating red line for any agreement providing for ISDS.

\section{A. Introduction}

In this paper I examine the Commission's new concept paper on ISDS in the proposed Transatlantic Trade and Investment Partnership (TTIP). The Commission's approach builds on the ISDS model already purportedly agreed by the European Commission in the Comprehensive Economic and Trade Agreement (CETA) with Canada and the Free Trade Agreement (FTA) with Singapore.

I reproduce large sections of the concept paper to respond to and at times debunk them. The details behind most of my responses are elaborated in other documents, especially my submission to the European Commission's public consultation on ISDS in 2014 and a more recent paper on the flaws with ISDS in the TTIP and CETA. These other papers are available at http:// ssrn.com/ author $=638855$.

My primary message is that the Commission's approach to reform is seriously inadequate. The Commission must by now be well aware of fundamental flaws in ISDS and the threat it poses to democracy, courts, and public budgets. It must also be aware that the evidence to show that ISDS delivers a public benefit commensurate with the potentially huge public subsidy it provides, mostly to large corporations and very wealthy individuals, is sparse at best. Yet, ISDS is still clearly being pushed hard by the Commission, as well as North American and some European governments, in a context-relations among countries with established democratic and judicial institutions - where it is clearly unjustified and likely to do significant harm to public institutions. Simply, the current push for ISDS is at the forefront of the situations in which voters and taxpayers are losing out badly, due to legal reforms that benefit most clearly the most powerful and wealthy economic actors in the world. 


\title{
B. Response to the Commission's initial claims about reform
}

\section{The Commission's concept paper begins with this "starting point":}

International investment rules were invented in Europe. Today, EU Member States are parties to almost half of the total number of international investment agreements that are currently in force worldwide (roughly to 1400 out of 3000). These agreements, almost all of which include both investment protection and investor-to-State dispute settlement ("ISDS") (which allows disputes between an investor and a State when the latter is alleged to have breached its commitments under an international investment agreement to be resolved) - have played their part in encouraging and protecting the high volume of EU investment abroad and, reciprocally, the investments held by the rest of the world in the EU.

This statement is misleading because the Commission does not make clear that international investment rules "were invented in Europe" as a means to discipline newly-independent countries among former colonies. The thrust of proposed treaties like the TTIP, CETA, and Trans-Pacific Partnership (TPP) is to extend those antidemocratic, non-judicial rules to developed countries too.

The Commission's statement also contains misleading information, by now well-worn as a sales pitch for ISDS, on the large number of existing treaties that allow for ISDS. Yet, the vast majority of those treaties are unlikely ever to lead to claims. Also, just a few new treaties, led by TTIP, would roughly triple the scope of ISDS judging by the amount of foreign investment flows to which ISDS would be directly applicable. We are at a major turning point in the potential expansion and locking-in of ISDS as a supreme decision-making body for the world.

Lastly, the Commission says that existing treaties "have played their part" in encouraging and protecting investments from and to Europe. Most clearly, this playing of their part has led to the transfer of billions of dollars in public funds to very large companies and very wealthy individual (and to ISDS lawyers and arbitrators). On the question of whether the treaties have encouraged or protected investments in a more general way, the evidence is at best mixed. If the treaties were more clearly named to reflect their direct financial effect of the treaties, they would be called Agreements to Transfer Public Money to Foreign Owners of Assets, Lawyers, and Arbitrators.

\section{The Commission continues by offering this rationale for the "need for a new EU} approach":

\begin{abstract}
The key challenge for the EU's reformed investment policy is the need to ensure that the goal of protecting and encouraging investment does not affect the ability of the EU and its Member States to continue to pursue public policy objectives. A major part of that challenge is to make sure that any system for dispute settlement is fair and independent. The EU has already begun to address these challenges, through interactions with EU stakeholders and through the process of negotiation of the first generation of EU trade agreements that included investment protection and ISDS.
\end{abstract}

Clearly, if the Commission's goal was to avoid interfering with the ability of legislatures and governments to "pursue public policy objectives" and if the goal was to safeguard existing judicial processes that are "fair and independent", the best way to achieve those goals would be to avoid giving foreign investors the ability to attack laws 
and regulations by threatening a financially-dangerous ISDS lawsuit against the European Union or a member country. As such, it is a key flaw in the Commission's approach to ISDS that the Commission does not lay out a compelling, evidence-based case that ISDS - as an effective subsidy for the most powerful and wealthy actors in the world-provides a benefit to the public. Such a case is not laid out in the Commission's concept paper or any of its other publications on ISDS.

\section{Response to the Commission's claims about its reform "so far" in the CETA}

Next, the Commission turns to what it has "achieved so far" in its reforms of ISDS in order to preserve public policy objectives and ensure that dispute resolution is fair and independent. As evidence, the Commission provides a list of examples, each of which I critique briefly below. In my criticism, I focus on the public text of the Canada-Europe CETA, not the Singapore-Europe FTA, although both are essentially the same for purposes of ISDS and its threat to democracy, courts, and public budgets.

The Commission's first example of a purported achievement is this:

We have reaffirmed the right to regulate. In CETA we have made clear in the preamble of the agreement that the EU and Canada preserve their right to regulate and to achieve legitimate policy objectives, such as public health, safety, environment, public morals and the promotion and protection of cultural diversity.

I think it strong but fair to say that this claim approaches the level of a fraud on the public. The key problem legally is that, by affirming the right to regulate in the CETA's preamble (and its labour and environment chapters) but not in the CETA's investment chapter, the CETA has created an implication that the preamble's affirmation of the right to regulate was intentionally not meant for the investment chapter. Otherwise, why did the parties not include it in the investment chapter as they did in other CETA chapters?

The Commission's next example is as follows:
We have defined key concepts like "fair and equitable treatment" and "indirect expropriation", in order to prevent abuse. For the first time, CETA provides a definition of these terms. "Fair and equitable treatment" is defined through a clear, closed text which defines precisely the content of the standard without leaving unwelcome discretion to arbitrators. Moreover, detailed language has been agreed upon to clarify what constitutes indirect expropriation, particularly excluding claims against legitimate public policy measures.

However, the approach to these concepts certainly does not prevent abuse or protect reliably the right to regulate, though it takes a long time to explain. To illustrate briefly, the approach taken in the CETA to "fair and equitable treatment" creates a greater risk of abuse and a greater threat to the right to regulate than the longstanding approach of Canada and the U.S. in NAFTA. I elaborated on the details of this issue in my submission to the Commission's public consultation in 2014 (available on the link I mentioned earlier in this paper).

My sadness here is that the Commission is relying on the inability of the public and policy-makers to look closely at the technical details of the law of ISDS to find out just how much the Commission's approach sacrifices the "right to regulate" and, in turn, 
how it undermines democratic choice, judicial finality, regulatory flexibility, and public budgets.

\title{
The Commission continues:
}

\begin{abstract}
We have prevented practices by investors such as "forum shopping", that is trying to pick the most suitable agreement to bring an ISDS claim. For example, the making of an investment or business re-organisation for the purpose of bringing a case (as is alleged Philip Morris has done to bring its case against Australia) is explicitly prohibited in CETA. No other ISDS agreement contains such a provision. Moreover, "mailbox" companies will not be able to bring cases to arbitration. Only companies with real business operations in the territory of one of the Parties will be covered by the investment protection provisions.
\end{abstract}

The Commission's approach in the CETA has limited the risk of forum-shopping, but it has not prevented it. Many U.S. companies will be able to sue the European Union and its member states under the CETA because the U.S. companies have "real business operations", as the Commission puts it, in Canada.

The Canadian economy is largely an extension of the U.S. economy and it is heavily U.S.-owned. When Canadian business organizations lobby for ISDS, one has to keep in mind that many members of those organizations are ultimately U.S. or other foreign investors in Canada.

Indeed, the whole "mailbox" company issue because largely moot if European countries accept ISDS with the U.S. and, to a significant extent, if they accept it with Canada. There is little need to exploit mailbox companies when U.S. companies or their subsidiaries in Canada can sue directly under the TTIP or CETA.

The Commission then turns to the issue of openness in ISDS:

We have introduced full, mandatory transparency of the arbitration process. CETA incorporates the UNCITRAL rules on transparency which will mean that all documents (submissions by the disputing parties, decisions of the tribunal) will be made publicly available. All hearings will be open to the public. Interested parties (NGOs, trade unions) will be able to make submissions.

I give credit to the Commission for moving away from the (frankly scandalous) acceptance of large-scale secrecy in ISDS by many member states. However, as I elaborated in my submission to the Commission in 2014, the CETA approach still allows for secret settlements with foreign investors-potentially involving changes to government decisions or public pay-outs-before an ISDS document is filed. It also allows issues of confidentiality in ISDS to be resolved outside of a judicial process.

\section{The Commission continues:}

We have given governments, not arbitrators, ultimate control over the interpretation of the rules. Under CETA, the EU and Canada can issue binding interpretations on how the provisions should be interpreted, and the ISDS Tribunal is obliged to respect those interpretations. These binding interpretations can also be made with respect to on- going ISDS cases. The ability for the Parties to the agreement to adopt binding interpretations is a safety valve in the event of errors by the tribunals (the likelihood of which is in any event eliminated by the clear drafting of the relevant investment protection standards). 
arbitrators using the reactive and legalistic mechanism that is highlighted here.

As I elaborated in my submission to the Commission in 2014, the mechanism of binding interpretations was always in NAFTA but has been used only twice, over a decade ago, to respond to adventurous interpretations of ISDS arbitrators. It is a lumbering mechanism not well-suited to regulating the immense but nimble power of ISDS arbitrators to interpret vague treaty language and, in turn, to discipline legislatures, governments, and courts and to re-allocate public funds.

The Commission also refers to the issue of arbitrator independence and impartiality:

We have included, for the first time, a code of conduct for arbitrators, ensuring the respect of high ethical and professional standards. CETA sets out precise and clearly defined procedures to follow to ensure full impartiality of arbitrators, for instance by requiring full disclosure of any situation which could give rise to real or perceived conflicts of interest (for instance previous work or links to law firms). CETA also includes concrete steps to allow to determine whether a conflict could arise or has arisen. In case an arbitrator is found not to comply with the code, he/ she will be replaced.

This reliance on a code of conduct was an extraordinarily weak response to the fundamental issues of independence and impartiality in ISDS. It did not put in place the usual institutional safeguards such as secure tenure, a set salary, an objective method of case assignment, and prohibitions on double-dipping as a lawyer and arbitrator. Even the provision for disclosure in the aspirational code, as mentioned here, cannot be reliably enforced due to the existence of secret ISDS cases that make it impossible for any outside party to verify whether an arbitrator has engaged in activities prohibited by the code. Again, these issues are elaborated in detail in my submission to the Commission in 2014.

\section{The Commission also notes:}

We have created rules ensuring the early dismissal of unfounded claims. Under CETA we have introduced a fast track system that will allow to reject unfounded or frivolous claims in just a matter of weeks.

This example of a "reform" was particularly jarring to the idea of a "fair and independent" process. Consider that the Commission was proposing here to allow arbitrators who are paid by the case - and thus have a financial interest in the claim going ahead - to decide whether the claim should be rejected at an early stage. I do not suggest that all arbitrators would be affected by the financial interest, but the mere fact of the financial interest alone would create justifiable doubts about any decision to allow a claim to proceed. Clearly, claims should be vetted by someone who does not profit from allowing the claim to go ahead.

The Commission also states:

We are making investors who bring a case and lose, pay for all the costs of the legal proceedings. This "loser pays principle", introduced for the first time ever in CETA, will not only discourage frivolous or unfounded claims but will also mean that the investor must pay the litigation costs of the state he has challenged (at present, even if a government 
successfully defends itself, it often has to bear its litigation costs). Given the financial risk, an investor will think twice before bringing any ISDS claim.

This "reform" operates in favour of the big players. It creates a disadvantage for smaller investors - in comparison to deep-pocketed ones-and to smaller states, all of which now face greater financial risks associated with ISDS litigation. In turn, for investors there is a more pressure to avoid bringing an ISDS lawsuit, while for states the pressure is to settle ISDS lawsuits in a way that favours deep-pocketed companies and individuals.

On the question of an appellate body, the Commission indicates:

We have had our negotiating partners agree to work towards a future appeals mechanism. The Commission has said already back in 2010 that an appellate mechanism has clear added value in ensuring consistency and predictability of the system and the idea of putting in place such a mechanism has broad support amongst EU stakeholders. CETA is the first agreement to which the US is not a party which contains a clear commitment to the possible creation of an appeal mechanism.

However, if the Commission was serious about an appellate body—which no country including the U.S. has ever agreed to establish-then obviously there was a greater opportunity to push Canada to establish one than to push the U.S. I see this aspect of the CETA-like many others that follow the U.S. government's approach since the early 2000s - as part of the signaling that the Commission is prepared to accept almost all aspects of the U.S. model of ISDS.

Finally, the Commission states:

And we oblige investors to drop cases in national courts if they want to pursue ISDS. CETA prohibits parallel proceedings: investors cannot seek remedies in domestic courts and through ISDS at the same time. The aim is to avoid double compensation and divergent verdicts. Most of the over 3,000 existing investment treaties with ISDS do not have this prohibition.

Essentially, the Commission is endorsing here a privileging of foreign investors over everyone else in international law. Normally, a private party has to go to domestic courts, where they are reasonably available, before bringing an international claim. Only foreign investors have been relieved of this requirement - and the Commission would expand this unjustified favourtism-based on an implied assumption that foreign investors, in all cases, cannot expect adequate protection in the courts of any country. Like everyone else, foreign investors should be required to provide evidence to demonstrate that they cannot access justice in the domestic courts of a country before being allowed to bring an international claim. The Commission has taken the opposite approach, again following on the U.S. model.

D. The Commission's proposed further reforms

After laying out these example of reforms that do not preserve policy-making flexibility or ensure fairness and independence in dispute resolution, the Commission turns to its purported "further" improvements and "a possible way forward" on four topics:

i) the protection of the right to regulate;

ii) the establishment and functioning of arbitral tribunals; 
iii) the review of ISDS decisions through an appellate mechanism; and

iv) the relationship between domestic judicial systems and ISDS.

There are positive aspects of this further reform agenda in the first three of these areas, but for the most part they take the same path of earlier pseudo reforms that leave ISDS and its flaws fundamentally intact.

I also stress that, without a legal text, any commitment to "reform" is essentially meaningless from a legal point of view. The Commission itself emphasizes (in bold) that its new proposals for reform are "without prejudice to the final position of the European Commission on the matters described within". That qualifier is especially worrying because the Commission's credibility in communicating a reform agenda is undermined by the fact that the Commission championed a deeply-flawed CETA text in misleading ways when it described the CETA in the public consultation on ISDS in 2014.

E. Criteria for evaluating the Commission's further reforms

Below, in my discussion of the Commission's further proposals, I rely on these criteria for evaluating ISDS:

- Is it independent, fair, and open in its process and institutional structure?

- Is it subsidiary in its relationship to other democratic, regulatory, and adjudicative institutions?

- Is it balanced in its accounting for (a) the state's right to regulate alongside foreign investor protections and (b) foreign investor responsibilities alongside foreign investor rights?

I suggest that these criteria are generally consistent with the democratic constitutional orders established or consolidated in Europe and North America during the twentieth century. As such, the criteria should be treated as the minimum for an ISDS proposal at the international level, if ISDS is not to undermine the basic idea that people should be able to elect a government that can viably implement social and economic reforms, subject to judicial protections of everyone's fundamental rights including property rights.

To elaborate briefly, by independent, I mean an ISDS process that is judicially independent in the manner of a court. By fair, I mean an ISDS process that provides a right of standing to all affected parties, including public notice of disputes in order to allow other affected parties to apply for standing. By open, I mean an ISDS process that is public in the manner of an open court.

By subsidiary, I mean a requirement that foreign investors must exhaust reasonablyavailable domestic remedies, that ISDSjudges must not proceed in parallel to domestic or contractually-agreed forums, and that ISDS judges should defer to democratically-accountable legislators or expert regulators faced with policy questions that are not well-suited for adjudication. 
By balanced, I mean the inclusion of a clear affirmation of the state's right to regulate in general, the provision for foreign investor responsibilities (actionable in the same manner as foreign investor rights), and the moderation of the remedy in ISDS so that states are not crippled in their law-making and regulatory functions by the risk of potentially massive financial liability.

I stress that, in a treaty among countries with established democracies and independent courts, the case for ISDS may still not be established, even if all the above criteria have been met. That is, states may still consider that the threat to democratic choice, judicial independence, regulatory flexibility, or public budgets is too great in comparison to whatever public benefit is thought to come from privileging and subsidizing foreign investors through ISDS.

\section{F. Response to the Commission's further reforms on the right to regulate}

The Commission's further reforms on the right to regulate are most relevant to the above criterion of balance. That is, a clear affirmation of the right to regulate in the investment chapter would provide at least a balance against the elaborate rights and protections of foreign investors. Also, limitations on the dangerous ISDS remedy of retrospective compensation would help to limit the risk of states being crippled in their law-making and regulatory functions by financial uncertainty.

On this issue, the European Commission's key statement is a (lukewarm) suggestion that the TTIP "should reaffirm the right to regulate in a legal provision in the body of the relevant chapter". The Commission then elaborates that the provision would be:

An operational provision (an Article) which will refer to the right of Governments to take measures to achieve legitimate public policy objectives, on the basis of the level of protection that they deem appropriate. Such provision is recognition of the right of domestic authorities to regulate matters within their own borders which exists already under international law. It allows setting the right context in which investment protection standards are applied.

If this proposal reflects a serious commitment, it is positive. However, it is not possible to evaluate the seriousness of the commitment without the legal language. Also, the suggestion is open to questions about the clarity of the affirmation since it is possible "refer to" the right to regulate, while rendering the right unreliable by clever drafting and qualifiers. Indeed, the record of the Commission so far raises some doubts about the seriousness of its commitment and about the dangers of leaving this issue to the negotiating process controlled by the Commission and by the U.S. or Canadian government.

To test the reliability of this reform commitment, I suggest that the starting point should be for the Commission to release precise language as a non-negotiable red line in the CETA, TTIP, and any other agreement that may provide for ISDS. Logically, the Commission would begin by laying out such a provision for the CETA and FTA that have already been negotiated (though not approved).

Beyond this commitment on the right to regulate, the Commission's proposed reforms are specific to limited examples of vague provisions or adventurous decisions in ISDS; in particular, on fair and equitable treatment and state aid. The proposed reforms do 
not envision a clear affirmation of the right to regulate and thus are relatively minor with respect to that element of the criterion of balance.

Unfortunately, the Commission carries on with the misleading spin that the CETA, for example, "already set a very high benchmark insofar as the protection of the right to regulate is concerned". The Commission bases this claim on some of the examples I critiqued earlier. In fact, the Commission's approach so far has done significant harm to the legal status of the right to regulate, undermining the Commission's credibility on this issue.

In summary, the Commission has still not committed to a clear affirmation of the right to regulate. More broadly, on the criterion of balance, the Commission has not proposed any meaningful steps to moderate the financially-dangerous remedy of restrictive damages or to include foreign investor responsibilities alongside foreign investor rights.

\section{G. Response to the Commission's further reforms on arbitral tribunals}

Next, the Commission turns to its proposals on "the establishment and functioning of arbitral tribunals in order to increase legitimacy of the ISDS system". This topic is relevant to various criteria outlined above, including independence, fairness, openness, and subsidiarity. Does the Commission deliver?

Unfortunately, the Commission begins with another defensive statement regarding its past approach to the stark lack of judicial safeguards in ISDS. Even if it were true (it is not) that the Commission's approach to arbitrator section and ethics "is already by far the most advanced in existence", as the Commission claims, the approach falls well short of basic standards of independent judging.

As the Commission acknowledges, the design of ISDS in the CETA is incompatible with judicial independence because (a) it enables an executive official to control case assignments and thus take steps to keep sensitive cases in safe hands, (b) it does not rely on an effective judicial "roster" from which all cases would be assigned to roster members on an objective basis such as rotation or lottery, (c) it relies, due to the existence of secret ISDS cases, on the goodwill of the arbitrators to disclose information that may give rise to a conflict of interest, (d) it subjects conflict of interest challenges against the arbitrators to resolution by an executive official instead of a judicial process, (e) it continues to rely on for-profit arbitrators where they are financially dependent on foreign investors to bring more claims, and (f) it gives foreign investors a direct role in half of the make-up of the tribunal that will determine issues of public importance and disburse potentially vast amounts of public funds.

Despite these serious flaws, the Commission actually describes its approach to this issue in the CETA as "a deep reform of the system". That statement is so misleading as to suggest the Commission lacks commitment to judicial independence in this context.

On the other hand, the Commission is more up front that its current approach is procedurally unfair because it does not "specifically provide for [a] right to intervene to persons with a clear and concrete interest in the case".

These points highlighted by the Commission relate to the criteria of independence and 
fairness, elaborated above. What further reforms does the Commission propose on these criteria?

On the positive side, for independence, the Commission proposes that all arbitrators would be chosen from a roster, the members of which are chosen by the states parties to the Agreement and are assigned to specific cases in an objective way. In particular:
A requirement that all arbitrators are chosen from a roster pre-established by the Parties to the Agreement (they could then be chosen either by lot or by choice of the disputing parties). This option would not present technical difficulties, and would allow to "break the link" between the parties to the dispute and the arbitrators. It would mean that all arbitrators have been vetted by the Parties.

Again, assuming that this is a serious commitment, it is a positive step that goes a significant way to addressing the lack of independence in ISDS.

Beyond this commitment, however, the Commission's proposals on qualifications for arbitrators are not significant. Indeed, the Commission says that the qualifications for arbitrators would focus on applying "international law as contained in the agreement". I take this statement as a signal to the ISDS industry that core members of the arbitration "club" will continue to play a prominent role. Considering how adventurously those core members have exercised their ISDS power, the Commission's approach, in my view, is a serious mistake. It would be much more reassuring if the Commission had signaled that other fields of expertise, such as public law and human rights (including property rights), would be represented among the roster members.

On the issue of fairness, the Commission briefly_but positively-says that the European Union proposal "should confer a right to intervene to third parties with a direct and existing interest in the outcome of a dispute". That would be an important step to address the current lack of fairness, although it is difficult to evaluate the proposal without a discussion of the notice requirements and rules of procedure needed to make the right operational (and in the absence of a legal text). It would also be more reassuring if the Commission had referred to "a right of standing" rather than "a right to intervene"; from my common law-based perspective, a right to intervene is a lesser right of participation than a right of standing.

Unfortunately, the negative aspects of the Commission's proposals are significant, especially on independence. My key concerns are that (a) the Commission still refers to arbitrators rather than judges, (b) the semantic point in (a) is important because the Commission does not commit to the arbitrators being paid a set salary instead of operating for-profit, (c) the Commission does not replace the role of executive officials in deciding conflict of interest claims with a proper judicial process and (d) the Commission does not commit to prohibiting arbitrators on the roster from working as ISDS lawyers during (or from having worked as ISDS lawyers for a reasonable period of, say, five years before and after) their service on the roster.

These gaps lead to the concern that the roster will end up populated or dominated by the same group of arbitrators who have misused ISDS power to date. The gaps in the Commission's proposals also intensify my concern that the proposals are not accompanied by precise language tied to clear red lines. 
I stress that these limitations in the Commission's proposal are vital because of the fundamental nature of the criteria of independence and fairness for an international adjudicative process that can override legislatures, governments, and courts and that carries potentially major financial implications for countries.

\section{H. Response to the Commission's further reforms on an appellate body}

The Commission also proposes an appellate mechanism in ISDS. On this topic, the Commission makes a significant statement-relevant to the criteria of independence and perhaps balance-as follows:

The EU proposal should include a bilateral appellate mechanism for ISDS. The EU text should lay out its role, its set-up and practical operation. The appellate mechanism would review awards as regards errors of law and manifest errors in the assessment of facts (this would include an incorrect factual treatment of domestic law as interpreted by domestic courts), ensure consistency in the interpretation of TTIP and increase legitimacy both on substance and through institutional design by strengthening independence, impartiality and predictability.

This is a positive, though still aspirational, description of an appellate body. The most positive aspect, to my eye, is that the statement includes details that indicate a degree of thought about what an appellate body would need to do. Also, the outline of issues that an appellate mechanism is proposed to consider is reasonable, especially because it includes issues of legal interpretation. That said, a lingering concern is that the appellate body would merely be superimposed on the for-profit arbitration process.

The Commission's statement continues by describing the appellate body as, effectively, a judicial body:

\footnotetext{
The bilateral appellate mechanism could be modelled largely on the institutional set-up of the WTO Appellate Body, with some adaptations both to make it specific for ISDS, and in light of experience in the WTO. There could be 7 permanent members ( 2 from each Party, 3 nonnationals) whose qualifications could be broadly similar to those of the WTO Appellate Body and/ or the International Court of J ustice. There would inevitably be certain costs associated with the establishment of the body including a possible secretariat to help the appellate members in their work. An appellate mechanism is a realistic possibility with the United States. The US has included a reference to the possible creation of an appellate mechanism in its agreements since 2002 .
}

The proposal is fairly vague on this point, but it seems that the Commission is considering an appellate body with judicial safeguards. My concerns in this respect are the Commission's apparent reticence about a dedicated secretariat for the appellate body, which would be important for its independence, and its flagging of the issue of whether the U.S. would even agree to this (or any other) proposals. This last proviso reiterates that the Commission's proposals can be evaluated properly only if laid out in a legal text.

I. Response to the Commission's further reforms on ISDS and domestic courts

The Commission's final proposal relates to the criterion of subsidiarity.

In introducing this proposal, the Commission unfortunately sidetracks to a dubious connection between the type of dispute resolution body-international versus domestic - and the source of the legal obligations. The Commission sidetracks in this 
way in order to claim that ISDS is needed because domestic courts may not be in a position to apply international law. Leaving aside this complex issue, the important issue is not whether domestic law or international law is the source of justice and protection for foreign investors (or anyone else) but rather whether adequate protection and access to justice has been afforded by domestic courts, from the perspective of international law. There is a variety of ways for the international standard of protection and access to justice to be assessed internationally, such as by a state-state tribunal or an international court.

In any event, the Commission at least acknowledges that "it still makes sense to try and manage better the relationship between domestic (judicial) and international (arbitration) remedies". However, the Commission then limits the means of managing this relationship to the avoidance of "the risk of double compensation (i.e. that investors could get compensation under domestic law and international law for the same damage)". The Commission also takes a very narrow approach to the issue of subsidiarity, saying that:

Both under CETA and the EU/ Singapore FTA, investors must withdraw from any domestic proceedings they may have started before submitting a claim to ISDS (this is the so-called "no u-turn" approach). Parallel claims are thus prohibited.

This statement is misleading because in fact, in the CETA (again, following the U.S. model), the foreign investor is required only to withdraw domestic proceedings that lead to monetary remedies. As I elaborated in my submission to the Commission in 2014, the foreign investor can thus have its cake and eat it too; that is, the investor can pursue monetary remedies in ISDS (where, dangerously, they are the primary remedy) while pursuing non-monetary remedies in domestic law (where monetary remedies are typically a secondary remedy for claims against the state acting in its sovereign capacity).

The key element that is missing from the Commission's proposal is a clear commitment to the requirement that foreign investors-like everyone else-must go to domestic courts first and seek an international remedy only if they show the domestic remedies were not reasonably available. It has been a radical change for ISDS to have relieved foreign investors of this conventional duty.

The Commission dances around this gap in its approach to ISDS by shifting to the much less significant issue of parallel proceedings and by saying for example:

... investors may first seek to obtain redress in domestic courts, including by exhausting domestic court proceedings, before possibly turning to ISDS where the treatment afforded by the country [including by its domestic courts] still allegedly falls short of the basic guarantees contained in the investment protection provisions of an international agreement. The rationale of this approach is to encourage investors to primarily rely on domestic remedies thus minimizing the potential number of ISDS claims.

The key word in this excerpt is the second word: "may". Foreign investors are not required to go to domestic courts before turning to ISDS. It is an option for foreign investors, unlike for everyone else (who incidentally do not have access to anywhere near the same wide-ranging and powerful protections enjoyed by foreign investors via ISDS). 
The Commission goes on by highlighting some insignificant proposals for "fork-in-theroad" or "no u-turn" clauses. Neither of these clauses would establish ISDS as subsidiary to domestic courts; neither has been applied effectively in most of the relevant ISDS cases because the arbitrators have devised legal techniques to avoid being limited by the clauses and to allow parallel treaty claims to go ahead, as noted in my submission to the Commission in 2014. The Commission's proposals on the relationship between ISDS and domestic law are likewise not significant on the criterion of subsidiarity.

As such, the Commission continues to endorse an enclave legal status to foreign investors by allowing them to challenge the laws and other decisions that apply to everyone, outside of the processes to which everyone else must resort. It is an unjustified privileging of foreign investors. It clearly contradicts the principle of subsidiarity in ISDS.

In summary, on subsidiarity, the Commission's approach falls well short. It does not mention issues related to contractually-agreed forums and to domestic legislators and regulators. Most importantly, the Commission's approach does not contemplate a duty for foreign investors to use domestic courts before going to ISDS. This is a major gap in the Commission's approach.

\section{J. Summary of responses to the Commission's further reforms}

The Commission refers to its TTIP proposals as "stepping stones" toward a multilateral system of ISDS. This aspect of the Commission's agenda causes me the most concern.

Logically, one would expect the Commission to address existing treaties that rely on the flawed system of ISDS before proposing to expand ISDS massively in a major new deal with the U.S. From this perspective, the existing CETA and FTA texts are like lowhanging fruit, ready to be picked. Why would the Commission not make clear that it will implement its vision for ISDS reform in the CETA and the FTA, both of which offer contexts in which the Commission has more bargaining power? Likewise, both of these other treaties leave the option of reform squarely on the table until they are ratified.

The Commission's lack of focus on these existing treaties suggests that it is contemplating reforms for two apparent purposes. The first is to distract from its endorsement of a deeply flawed ISDS system in the CETA. The second is to soften up decision-makers for the prospect of a TTIP by offering potential ISDS reforms-all dependent on agreement by a more powerful negotiating partner-to keep the ball rolling.

This last aspect of the Commission's proposal casts doubt on the whole enterprise. That is, putting one's faith in the Commission's commitment to serious reform would be misplaced until the Commission's proposals are accompanied by a clear legal text that is identified as a red line for all treaties negotiated by the Commission, including the CETA and FTA. There are also serious gaps in the Commission's reform approach, even accepting that they are genuine proposals and wishing away the risk that key components will be conceded in future negotiations, especially with the U.S. 
In particular:

- On independence, (a) the Commission still refers to arbitrators instead of judges,

(b) the Commission does not commit to the arbitrators being paid a set salary instead of operating for-profit, (c) the Commission does not replace the role of executive officials in deciding conflict of interest claims with a proper judicial process, and (d) the Commission does not commit to prohibiting arbitrators from working as ISDS lawyers during (and from working as ISDS lawyers for a reasonable period of, say, five years before and after) their service on the roster. Notably, the Commission's proposal for an appellate body also appears to contemplate an ongoing role for for-profit arbitrators. More broadly, the Commission appears to leave open the prospect that the same core group of arbitrators would populate or dominate the roster.

- On fairness, the Commission's proposal is brief, but it signals that all affected parties might be given a right of intervention. While this step would be positive, the proposal lacks sufficient detail to evaluate it properly.

- On openness, the Commission to its credit has moved away from the acceptance of large-scale secrecy in ISDS, but its approach would still allow for secret settlements with foreign investors before a formal ISDS document is filed. It also allows issues of confidentiality to be resolved outside of a judicial process.

- On subsidiarity, the Commission continues to avoid the elephant in the room. Why should foreign investors be relieved from the usual requirement to go to domestic courts first, unless they can show that domestic courts do not offer justice? The point has been laid out in detail to the Commission; it is a deep concern that the Commission has not incorporated this basic requirement. In turn, the Commission appears to be set on continuing to give foreign investors an unjustified privileged status, relative to everyone else. Finally, the Commission does not mention other issues of subsidiarity concerning contractually-agreed forums, domestic legislators, and domestic regulators.

- On balance, the Commission offers a positive signal on the right to regulate. Yet, the devil is in the details and, given the Commission's misleading spin of this issue, it seems prudent to wait for a precise legal text and a clear red line before relying on the reform proposal. Also, the Commission has not ameliorated the serious risk of potentially massive financial liability for states by limiting the remedy of retrospective damages. That is a major omission. Finally, for anyone wanting actionable responsibilities for foreign investors alongside their rights, the Commission has avoided that issue of balance entirely.

In 2007, I floated an idea for an international investment court in an academic book on ISDS. Yet, I am more melancholy than inspired by the Commission's proposal to create a "permanent investment court with tenured judges" due to the Commission's approach to sequencing. It is very clear that the priority should be to replace ISDS in existing treaties, including those that have been negotiated and that are still within the Commission's power. The idea of a permanent court should not be used to justify a massive expansion of ISDS in the TTIP, based on ambiguous promises of institutional reform. 
I have seen quite a few reforms proposals that were deeply flawed but still promoted heavily by trade ministries and the ISDS legal industry. I've learned to wait for the text before accepting promises of ensuring independence, fairness, openness, subsidiarity, or balance. So far, in every case, the "reforms" that emerged in the texts have led to the same destination: the unjustified privileging of foreign investors - especially the most powerful and wealthy actors in the world - and a serious threat to democracy, courts, and public budgets.

This last comment is not meant to detract from the efforts of those working to achieve a better process for resolving disputes about foreign investment. It is to say that I will believe it when I see it. In the meantime, I wait for evidence of a commitment to fixing what is wrong now in the CETA and FTA instead of making things much worse by putting ISDS in the TTIP. 